\title{
Imaging VEGF receptor expression to identify accelerated atherosclerosis
}

\author{
Yared Tekabe ${ }^{1}$, Maria Kollaros ${ }^{1}$, Adam Zerihoun', Geping Zhang ${ }^{1}$, Marina V Backer ${ }^{2}$, Joseph M Backer² \\ and Lynne L Johnson ${ }^{1 *}$
}

\begin{abstract}
Background: The biology of the vulnerable plaque includes increased inflammation and rapid growth of vasa vasorum, processes that are associated with enhanced vascular endothelial growth factor (VEGF)/ imaging receptors for VEGF (VEGFR) signaling and are accelerated in diabetes. This study was designed to test the hypothesis that VEGFRs in atherosclerotic plaques with a SPECT tracer scVEGF-PEG-DOTA ${ }^{99 \mathrm{~m}} \mathrm{Tc}(\mathrm{scV} / \mathrm{Tc}$ ) can identify accelerated atherosclerosis in diabetes.

Methods: Male apolipoprotein E null $\left(\mathrm{ApoE}^{-/-}\right)$mice ( 6 weeks of age) were made diabetic $(n=10)$ or left as non-diabetic $(n=13)$. At 26 to 28 weeks of age, 5 non-diabetic mice were injected with functionally inactivated $\mathrm{scV} / T \mathrm{c}$ (in-scV/Tc) that does not bind to VEGF receptors, while 8 non-diabetic and 10 diabetic mice were injected with scV/Tc. After blood pool clearance, at 3 to $4 \mathrm{~h}$ post-injection, mice were injected with $\mathrm{CT}$ contrast agent and underwent SPECT/CT imaging. From the scans, regions of interest (ROI) were drawn on serial transverse sections comprising the proximal aorta and the percentage of injected dose (\%ID) in ROls was calculated. At the completion of imaging, mice were euthanized, proximal aorta explanted for gamma well counting to determine the percentage of injected dose per gram $(\% / \mathrm{D} / \mathrm{g})$ uptake and immunohistochemical characterization.
\end{abstract}

Results: The uptake of scV/Tc in the proximal aorta, calculated from SPECT/CT co-registered scans as \%ID, was significantly higher in the diabetic mice $(0.036 \pm 0.017 \% \mathrm{ID})$ compared to non-diabetic mice $(0.017 \pm 0.005 \% \mathrm{ID}$; $P<0.01$ ), as was uptake measured as $\% \mathrm{ID} / \mathrm{g}$ in harvested aorta, $1.81 \pm 0.50 \% \mathrm{ID} / \mathrm{g}$ in the diabetic group vs. $0.98 \pm 0.25 \% \mathrm{lD} / \mathrm{g}$ in the non-diabetic group $(P<0.01)$. The nonspecific uptake of in-scV/Tc in proximal aorta was significantly lower than the uptake of functionally active $\mathrm{scV} / \mathrm{Tc}$. Immunostaining of the atherosclerotic lesions showed higher expression of VEGFR-1 and VEGFR-2 in the diabetic mice.

Conclusion: These initial results suggest that imaging VEGFR with scV/Tc shows promise as a non-invasive approach to identify accelerated atherosclerosis.

Keywords: Vascular endothelial growth factor; Atherosclerosis; Molecular imaging

\section{Background}

Rupture of an atherosclerotic plaque in the coronary or carotid arteries can lead to sudden and lethal events. A non-invasive imaging approach for detection of atherosclerotic plaques that are prone to rupture would allow for timely preventive treatment and therefore would have a significant clinical impact. In addition to targeting plaque inflammation with ${ }^{18} \mathrm{FDG}$, a number of specific

\footnotetext{
*Correspondence: lj2129@cumc.columbia.edu

'Department of Medicine, Columbia University Medical Center, 622 West 168th St, PH 10 center rm 203, New York, NY 10032, USA

Full list of author information is available at the end of the article
}

biomarkers, such as P-selectin, VCAM, metalloproteinases, and integrins have been investigated for imaging in mouse models and in human endarterectomy specimens [1-7].

Key characteristics of vulnerable plaques include rapid plaque growth accompanied by outward vessel remodeling without increases in luminal narrowing, increased inflammation, and rapid growth of both the hypoxic central core and adventitial vasa vasorum [8]. As expected for pathologies involving inflammation and hypoxia, plaque development is associated with increase in the expression of vascular endothelial growth factor (VEGF)

\section{实}


and its receptors (VEGFRs) by endothelial cells, macrophages, and other plaque constituent cells. VEGF/VEGFR signaling has been implicated in the development of atherosclerosis and plaque vulnerability [8-14] particularly in association with diabetes [15-17].

Since the prevalence of VEGFRs, specifically VEGFR-1 and VEGFR-2, in vulnerable plaques is increased relative to more stable ones, we hypothesized that VEGFR imaging might provide a useful biomarker for assessing plaque vulnerability. To test this hypothesis we used SPECT molecular imaging for quantifying VEGFR prevalence in plaques in apolipoprotein null $\left(\mathrm{ApoE}^{-/-}\right)$mice in which complex plaque development is accelerated by induction of diabetes.

For VEGFR imaging, we employed previously described scVEGF-PEG-DOTA $/{ }^{99 \mathrm{~m}} \mathrm{Tc}$ SPECT tracer, $(\mathrm{scV} / \mathrm{Tc})$, based on an engineered single-chain (sc) recombinant VEGF, site-specifically derivatized with PEGylated chelator DOTA [18-21]. scVEGF-PEG-DOTA conjugate appears to be a versatile platform for the developing of VEGFRtargeting imaging tracers and radiopharmaceuticals. Various scVEGF-based imaging tracers retain nanomolar affinity to VEGFRs, are readily internalized upon binding to the receptors, and reliably detect VEGFR in animal models of cancer [22,23], aortic aneurism [24], graft atherosclerosis [25], and inflammation [26,27]. Uptake of scVEGF/Cy5.5 by NIRF imaging of in human carotid endarterectomy specimens localized to expression of VEGFR1 and VEGFR2 and histological characteristics of intraplaque capillary density and infiltrating macrophages [28]. Importantly, the nonspecific uptake of scVEGFbased tracers is evaluated using corresponding tracers based on functionally inactivated scVEGF that does not bind to VEGFRs [19].

\section{Methods}

\section{Animals}

All animal studies were performed with the approval of the Institutional Animal Care and Use Committee of Columbia University. Male C57BL/6 mice and $\mathrm{ApoE}^{-/-}$ mice with the genetic background of C57BL/6 mice were purchased from The Jackson Laboratories (Bar Harbor, ME, USA).

\section{Induction of diabetes}

At 6 weeks of age, mice were made diabetic via 5 consecutive daily doses of streptozotocin (Sigma, $50 \mathrm{mg} / \mathrm{kg}$ in citrate buffer, $\mathrm{pH}$ 4.5; St. Louis, MO, USA). Blood glucose levels were monitored weekly via tail vein sampling using blood glucose monitor (FreeStyle Lite, Abbott, North Chicago, IL, USA). The mean blood glucose level for the duration for diabetic mice was $309 \pm 39 \mathrm{mg} / \mathrm{dL}$. Animals were studied at 26 to 28 weeks of age. On arrival, all of the apoE-/-mice had similar weights, but by the time of study, the diabetic mice were smaller than the non-diabetic mice with average weights of $23.1 \pm 1.2$ and $30.7 \pm 1.1 \mathrm{~g}(P=0.0001)$.

\section{Radiotracer preparation}

$\mathrm{scV} / \mathrm{Tc}$ is based on scVEGF protein which combines two 3 to 112 fragments of human VEGF fused head to tail and is expressed with an N-terminal 15-aa cysteinecontaining tag (Cys-tag) for site-specific conjugation [19]. scVEGF-PEG-DOTA and its inactivated analog that lacks VEGFR-binding ability were prepared as described [19]. Briefly, scVEGF was site-specifically derivatized on $\mathrm{C} 4$ in Cys-tag with radionuclide chelator 1,4,7,10tetraazacyclododecane-1,4,7,10-tetraacetic acid (DOTA) via $3.4 \mathrm{kDa}$ PEGylated linker. The inactivated VEGFPEG-DOTA was prepared by biotinylation of 10 to 12 lysine $\varepsilon$ amino groups in scVEGF moiety. For ${ }^{99 \mathrm{~m}}$ Tc labeling, lyophilized $0.15 \mathrm{mg}$ scVEGF-PEG-DOTA (approximately $5 \mathrm{nmol}$ ) was reconstituted with $75 \mu \mathrm{l}$ of $0.1 \mathrm{M}$ $\mathrm{NaOAc}$ buffer (pH 5.5) and added to 30 to $40 \mathrm{mCi}(1,110$ to $1,480 \mathrm{MBq}$ ) of ${ }^{99 \mathrm{~m}} \mathrm{Tc}$. The mixture was purged with $\mathrm{N}_{2}$ for $2 \mathrm{~min}$ followed by addition of $50 \mu \mathrm{g}$ of tin-tricine in $450 \mu \mathrm{l}$ of deionized water, briefly purged with $\mathrm{N}_{2}$ and incubated for $20 \mathrm{~min}$ at $55^{\circ} \mathrm{C}$. Free ${ }^{99 \mathrm{~m}} \mathrm{Tc}$ was separated on PD-10 column (Pharmacia) equilibrated with PBS/0.1\% BSA. Fractions $(0.5 \mathrm{ml})$ containing the tracer in the void volume were pooled. The radiochemical purity of $\mathrm{scV} / \mathrm{Tc}$ was $97 \% \pm 1.6 \%$ with the specific activity of $109 \pm$ $11 \mu \mathrm{Ci} / \mu \mathrm{g}$. The inactivated scVEGF-PEG-DOTA was similarly labeled with ${ }^{99 \mathrm{~m}} \mathrm{Tc}$ and the resulting tracer was named in-scV/Tc.

\section{Blood pool clearance and biodistribution}

Blood pool clearance was measured in 3 C57BL/6 mice and $3 \mathrm{ApoE}^{-1-}$ diabetic mice. Blood samples were taken by tail vein knicking at $5,10,30,60,90,200,250$, and $350 \mathrm{~min}$. Biodistribution of scV/Tc in non-target organs was analyzed in diabetic and non-diabetic mice after imaging. At necropsy, organs were removed, weighed, and counted in the well counter (Wallac Wizard 1470, PerkinElmer, Waltham, MA, USA).

\section{SPECT/CT imaging}

Non-diabetic ApoE ${ }^{-/-}$mice $(n=8)$ and diabetic $\mathrm{ApoE}^{-/-}$ mice $(n=10)$ mice were anesthetized with isofluorane ( $4 \%$ to induce, $1 \%$ to maintain) and injected with $\mathrm{scV} / \mathrm{Tc}$ $0.38 \pm 0.08 \mathrm{mCi}(14.06 \pm 2.92 \mathrm{MBq})$ via femoral vein catheter. To assess nonspecific (non VEGFR-mediated) tracer uptake, a separate group of non-diabetic $\mathrm{ApoE}^{-/-}$ mice $(n=5)$ were injected with in-scV/Tc (tracer control). To assess uptake of tracer in non-diseased mice, 2 C57BL/6 mice were injected with scV/Tc (disease control). Three to $4 \mathrm{~h}$ after tracer injection (blood pool clearance), all mice were re-anesthetized and injected with 150 to 
$200 \mu \mathrm{l}(160 \mathrm{mg} / \mathrm{mL})$ of eXIA contrast agent (Binitio Biomedical, Ottawa, Canada) and immediately underwent SPECT/CT imaging on nanoSPECT/CT system (Bioscan, Washington DC, USA).

CT images were acquired with an integrated CT scanner using an X-ray tube at $45 \mathrm{kVp}$ and an exposure time of $1,000 \mathrm{~ms}$ per view. The helical SPECT scans were acquired using dual-headed detectors each outfitted with collimators with nine pinholes. Each pinhole had a diameter of $1.4 \mathrm{~mm}$ with each collimator providing a transaxial field-of-view (FOV) of $30 \mathrm{~mm}$ and an axial FOV of $16 \mathrm{~mm}$, extendable through helical scanning to $270 \mathrm{~mm}$. SPECT data were acquired with the following parameters: step and shoot rotation, $30^{\circ}$ step in $360^{\circ}$ rotation using 24 projections, $60 \mathrm{~s}$ per projection, $256 \times 256$ frame size with $1.0 \mathrm{~mm}$ pixels, and $140 \mathrm{keV}$ with $10 \%$ energy window. The obtained projection data were reconstructed by ordered subset expectation-maximization algorithm with subset and iteration number set to 16 and 8 , respectively, and a voxel size of $300 \mu \mathrm{m}$ and SPECT and CT datasets fused. At the end of imaging, mice were euthanized by an intraperitoneal injection of pentobarbital $(100 \mathrm{mg} / \mathrm{kg})$.

\section{Image analyses}

The scans were reconstructed and processed using InVivoScope software (Invicro, Boston, MA, USA). Tracer uptake identified as focal areas of activity in the ascending aorta, arch, and brachiocephalic trunk were identified on transverse sections by triangulating from coronal and/or sagittal images and using contrast in the vessels on the CTA for anatomical localization. Regions of interest (ROIs) were drawn around all these areas of focal activity and counts in the ROIs converted to $\mathrm{mCi}$ using a calibration algorithm and activity for all regions summed for the total vascular tracer uptake (Figure 1). The summed activity from the ascending aorta and arch (excluding the brachiocephalic vessels) was correlated with ex vivo gamma counting of the same tissue. To address whether there were differences in blood pool activity between the diabetic and non-diabetic mice at the time of imaging, ROIs were drawn in the center of the mid-LV cavity on the transverse slice to measure activity $\left(\right.$ in $\mathrm{mCi} / \mathrm{mm}^{3}$ ).

\section{Ex vivo gamma well counting}

The chest was opened and the proximal aorta and arch and brachiocephalic vessels photographed in situ. Due to time-consuming and technical challenges in dissecting the brachiocephalic vessels, the proximal aorta and arch showing plaque was dissected for correlation with activity measured on scans for the same anatomical segments. The fragment were excised and washed in PBS and weighed, and the radioactivity was counted in a gamma well counter (Wallac Wizard 1470, PerkinElmer, Waltham, MA, USA) and expressed as the percentage of injected dose per gram (\%ID/g) of tissue. Radiotracer accumulation in non-target organs was determined similarly.

\section{Histology and immunohistochemistry}

The proximal aorta was harvested and fixed for $24 \mathrm{~h}$ in formalin (10\%) and paraffin-embedded. Tissue blocks were sectioned (5- $\mu \mathrm{m}$-thick) and stained with hematoxylineosin (H\&E) for morphological evaluation. Serial sections (5- $\mu \mathrm{m}$-thick) were deparaffinized in xylene, treated with $0.3 \%$ hydrogen peroxide for $20 \mathrm{~min}$, followed by incubation in protein-free block (Dako, Carpinteria, CA, USA) for $10 \mathrm{~min}$ to inhibit the nonspecific binding of the primary antibody. Sections were stained for macrophage marker Mac-3 (RM0029-11H3, rat monoclonal antibody, 1:50 dilution, Santa Cruz Biotechnology, Dallas, TX, USA), VEGFR-1 (rabbit monoclonal antibody, 1:100 dilution, Abcam, Cambridge, MA, USA), VEGFR-2 (rabbit monoclonal antibody, 1:1,500 dilution, Cell Signaling Technology, Beverly, MA, USA), and pan-endothelial cell marker FVIII (rabbit polyclonal antibody, 1:250 dilution, Dako, Carpinteria, CA, USA). Detection was performed with HRP-conjugated respective secondary system followed by diaminobenzidine (DAB substrate kit for peroxidase, Vector Laboratories) and counterstaining with Gill's hematoxylin solution.
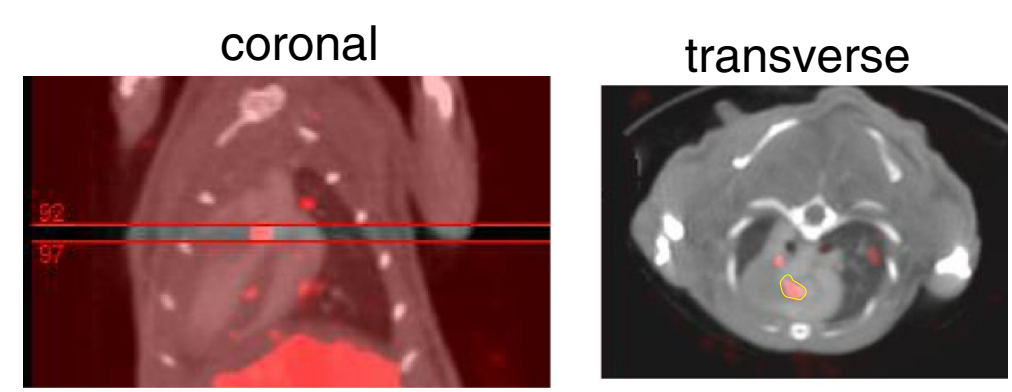

Figure 1 Method for ROI placement for quantification. Slices comprising the focal uptake (red color table) are identified on the coronal projection, and an $\mathrm{ROI}$ is drawn around the uptake on the transverse projection. The counts in this region are converted to $\mathrm{mCi}$ using a calibration standard that is loaded into the software. 
Morphometric and immunohistochemical analyses of the arterial segments were performed using a Nikon microscope and Image-Pro Plus software (Media Cybernetics Inc., Silver Spring, MD, USA). The plaque area in the proximal aorta was measured as percent lesion area per total area of the aorta. The positively stained area in the lesion for each marker was calculated as percentage of immunostained area per total area of the vessel.

\section{Immunofluorescence}

To determine the cell types expressing VEGFR-1 and VEGFR-2 in aortic lesions, dual fluorescent confocal microscopy studies were undertaken. Briefly, aortic sections (5- $\mu \mathrm{m}$-thick) were stained for VEGFR-1 and VEGFR with the respective antibodies as described above. The slides were then incubated with fluorescent tagged secondary antibodies (Texas Red) and co-stained with fluorescent antibodies for endothelial cells (anti-FVIII, 1:200; fluorescein isothiocyanate) or macrophages (anti-Mac-3, 1:50; fluorescein isothiocyanate). The images were examined using confocal fluorescence microscope (Nikon, Melville, NY, USA) and SPOT imaging software (Diagnostic Instruments, Inc., Sterling Heights, MI, USA).

\section{Statistical analysis}

Data are reported as means \pm standard deviation. Statistical comparisons between the diabetic and non-diabetic groups and between the inactivated and active tracers were made using Welch's $t$ test for groups of unequal size and variance. Estimated power to detect an observed twofold difference between groups of non-diabetic mice imaged with inactivated tracer $(n=5)$ vs. active tracer $(n=8)$ is better than 0.8 ; and between groups of nondiabetic $(n=8)$ vs. diabetic mice $(n=10)$ imaged with active tracer is better than 0.95 . Differences between the groups were considered significant at a value of $P<0.05$. Correlation for individual values for tracer uptake between scan and well counting was assessed using the Pearson product-moment correlation coefficient.

\section{Results}

\section{Blood pool clearance and biodistribution}

The clearance of scV/Tc in diabetic $\mathrm{ApoE}^{-/-}$and $\mathrm{C} 57 \mathrm{BL} / 6$ mice was fitted to similar biexonential curves with $t_{1 / 2}$ for the first component of the curve $10 \mathrm{~min}$ and for the second $150 \mathrm{~min}$ (Figure 2A for diabetic $\mathrm{ApoE}^{-/-}$mice). The biodistribution of $\mathrm{scV} / \mathrm{Tc}$ in non-target organs of non-diabetic and diabetic $\mathrm{ApoE}^{-/-}$mice was found to be similar, with highest uptake in the kidneys and liver (Figure 2B).

\section{Scans}

Scans from diabetic and non-diabetic $\mathrm{ApoE}^{-1-}$ mice showed unequivocal uptake of $\mathrm{scV} / \mathrm{Tc}$ in the proximal aorta and

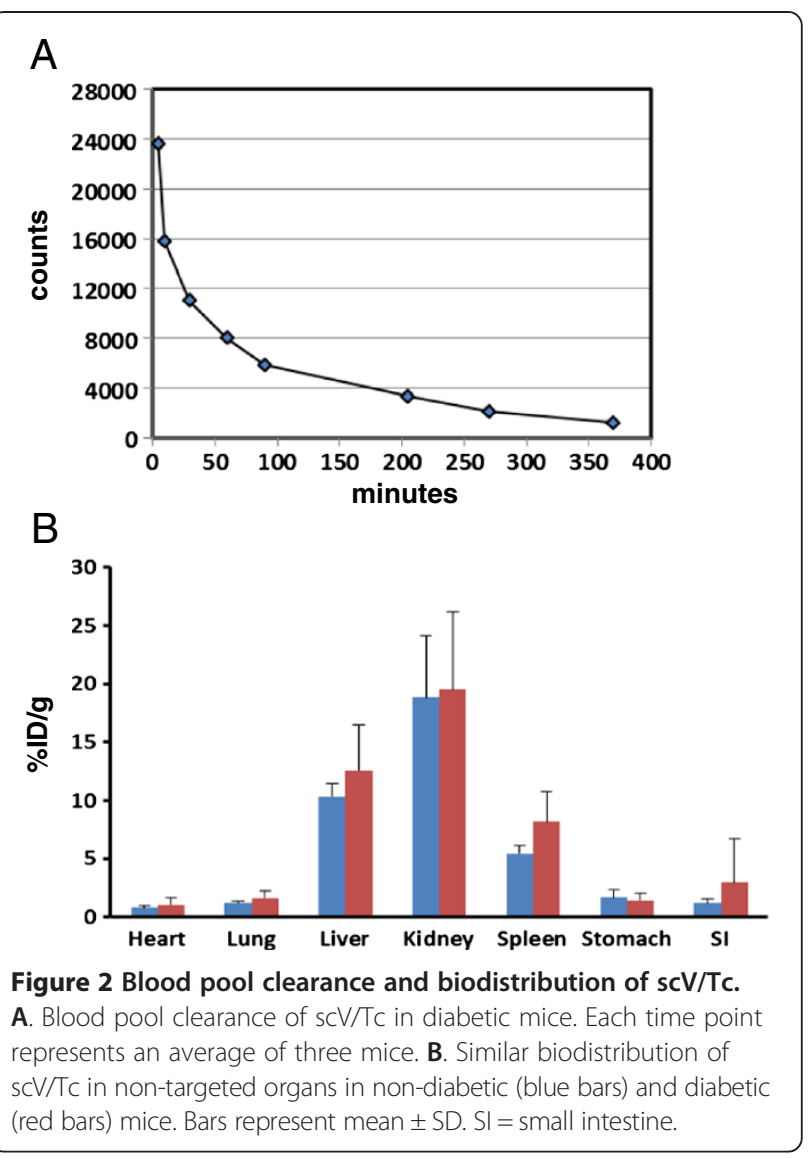

arch on the co-registered CT scan (Figure 3A,B,C,D as representative scans) with tracer uptake extending into the brachiocephalic vessels in the diabetic mice (compare representative scan Figure 3A,B for diabetic vs. Figure $3 \mathrm{C}, \mathrm{D}$ for non-diabetic). $\mathrm{ApoE}^{-/-}$mice injected with in-scV/Tc and C57BL/6 mice injected with $\mathrm{scV} / \mathrm{Tc}$ showed little or no tracer uptake in areas corresponding to the location of the proximal aorta and arch on the coregistered SPECT/CT scan (Figure 3E,F,G,H).

The blood pool activity levels determined from the scans for the non-diabetic and diabetic mice were not significantly different: $18.6 \times 10^{-3}$ vs. $19.4 \times 10^{-3} \mathrm{mCi} / \mathrm{mm}^{3}$ $(P=0.86)$.

\section{Lesion size}

The mean cross-sectional area of the proximal aortic lesions, expressed as percent lesion area over total aortic area, in the diabetic group $(32.3 \% \pm 6.05 \%)$ was significantly larger than in the non-diabetic group receiving scV/Tc $(15.3 \pm 4.3 \% ; P<0.01)$ The lesion size in the nondiabetic $\mathrm{ApoE}^{-/-}$mice receiving the in-scV/Tc $(12.0 \% \pm$ $2.9 \%$ ) was not statistically different from the non-diabetic mice receiving $\mathrm{scV} / \mathrm{Tc}$. 


\section{Tracer uptake quantitation}

The average uptake of $\mathrm{scV} / \mathrm{Tc}$ or in-scV/Tc in thorax areas corresponding to the proximal aorta, arch, and brachiocepahalic vessels was calculated from scans as \%ID, as described in Methods (Figure 4A). The average uptake of $\mathrm{scV} / \mathrm{Tc}$ in diabetic $\mathrm{ApoE}^{-/-}$mice was significantly higher than in non-diabetic $\mathrm{ApoE}^{-/-}$mice $(0.036 \pm$ 0.017 vs. $0.017 \pm 0.005 \% \mathrm{ID} ; P<0.01$ ) (Figure $4 \mathrm{~A}$ ). The non VEGFR-mediated uptake of in-scV/Tc in $\mathrm{ApoE}^{-/-}$mice, was significantly lower than that of functionally active $\mathrm{scV} / \mathrm{Tc}$ in age-matched $\mathrm{ApoE}^{-1-}$ mice with similar size lesions $(0.008 \pm 0.005$ vs. $0.017 \pm 0.005 \% \mathrm{ID} ; P<0.01)$.

These findings were confirmed by ex-vivo gamma well counting of harvested fragments of aorta with the most conspicuous plaques (Figure 4B). Uptake of scV/Tc calculated for these fragments as \%ID/g in diabetic $\mathrm{ApoE}^{-/-}$ mice $(1.81 \pm 0.50 \% \mathrm{ID} / \mathrm{g})$ was significantly higher than that in the non-diabetic ApoE ${ }^{-/-}$group $(0.9 \pm 0.25 \% \mathrm{ID} / \mathrm{g}$,
$P<0.01)$. In fragments harvested from non-diabetic $\mathrm{ApoE}^{-/-}$mice with similar extent of atherosclerosis the nonspecific (non VEGFR-mediated) uptake of in-scV/Tc $(0.44 \pm 0.12 \% \mathrm{ID} / \mathrm{g})$ was significantly lower than $\mathrm{scV} / \mathrm{Tc}$ uptake $(\mathrm{P}<0.01)$. Tracer uptake in the proximal aorta and arch of each mouse, determined as \%ID from scans, plotted vs. \%ID/g (well counter) determined for the same anatomical aortic section in the same mouse correlated significantly, $(r=0.75, P=0.0017)$ (Figure 4C).

\section{Histology and quantitative immunohistolchemistry}

Lesions from the diabetic $\mathrm{ApoE}^{-/-}$mice showed complex plaque anatomy with cholesterol clefts whereas lesions from age-matched non-diabetic $\mathrm{ApoE}^{-/-}$mice were at an earlier (fatty streak) stage. Immunostaining of serial sections through the plaque in the proximal aorta revealed greater staining for VEGFR-1, VEGFR-2 in the diabetic group than in the non-diabetic group, and this staining 


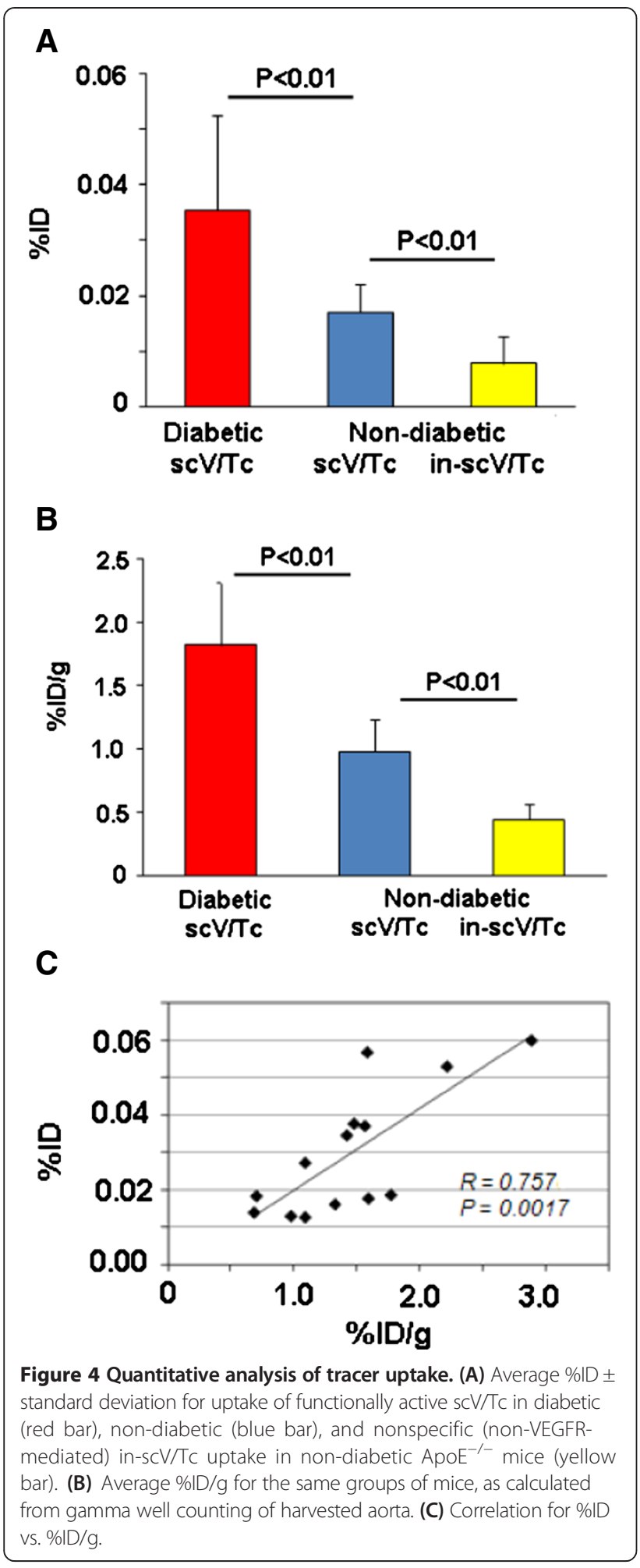

was observed on the luminal aorta surface as well as in the inner plaque area enriched in cells stained for endothelial marker FVIII and macrophage marker Mac-3 (Figure 5). Quantitative immunohistochemistry of the aortic tissue revealed greater expression of VEGFR-1 in the diabetic mice $(9.17 \% \pm 4.46 \%)$ compared with the nondiabetic $(1.88 \% \pm 1.48 \% ; P<0.01)$. Similarly, VEGFR-2 expression was significantly higher in the diabetic mice $(3.25 \% \pm 1.27 \%)$ compared with the non-diabetic $(1.31 \% \pm$ $0.86 \% ; P<0.01)$. Total macrophage burden in the atherosclerotic lesions of diabetic mice $(5.85 \% \pm 2.86 \%)$ was also significantly higher compared with the non-diabetic mice $(0.99 \% \pm 0.38 \% ; P<0.01)$. Immunofluorescence studies showed co-localization of VEGFR-1 primarily with macrophage marker Mac3 and VEGFR-2 with endothelial cell marker FVIII (Figure 6).

\section{Discussion}

This is the first study to report the results of in vivo SPECT imaging of a ${ }^{99 \mathrm{~m}}$ Tc-labeled VEGFR-targeting molecular tracer $(\mathrm{scV} / \mathrm{Tc})$ to detect more advanced complex lesions in diabetic $\mathrm{ApoE}^{-/-}$mice compared to age matched non-diabetic $\mathrm{ApoE}^{-/-}$mice with fatty streaks. We showed that the $\mathrm{scV} / \mathrm{Tc}$ uptake is predominantly VEGFR-mediated by showing significantly lower uptake of in-scV/Tc, incapable of VEGFR binding.

According to the current models of plaque progression, enhanced VEGF/VEGFR signaling plays an important role in three critical processes leading to plaque vulnerability: stimulation of angiogenesis in plaque, recruitment of monocytes into plaque, and increasing permeability of plaque vasculature which leads to hemorrhage and inflammatory cell extravasation $[8,10]$. Importantly, studies of accelerated atherosclerosis and enhanced plaque vulnerability in human diabetic patients, as well as in diabetic rabbit and mouse atherosclerosis models, revealed higher prevalence of VEGF and VEGFRs in diabetic vs. non-diabetic plaques [15-17]. Immunohistochemical analysis confirmed that the significantly higher uptake of the functionally active $\mathrm{scV} / \mathrm{Tc}$ in the more advanced and complex atherosclerotic lesions in diabetic vs. non-diabetic $\mathrm{ApoE}^{-1-}$ mice was due to higher prevalence of both VEGFR-1 and VEGFR-2. Although in this study, we did not image $\mathrm{ApoE}^{-1-}$ mice fed with high-fat (Western) diet to accelerate atherosclerosis since the lesion histology in the diabetic mice is very similar to that of mice at the same age fed with highfat (Western) diet [29].

Some variation in nonspecific uptake of the inactivated in-scV/Tc tracer was noted among mice; however, the level of uptake was significantly lower than receptormediated uptake of scV/Tc. This small amount of nonspecific trapping of a protein-based tracer was probably a result of the enhanced permeability and retention effects in inflammatory atherosclerotic tissue.

The diversity of VEGFR-expressing cells raises the question which cells are responsible for $\mathrm{scV} / \mathrm{Tc}$ uptake. In agreement with other studies [10,14,28], our immunohistochemical analysis indicates that in atherosclerotic plaques, VEGFR-2 receptors in this $\mathrm{ApoE}^{-/-}$model are 

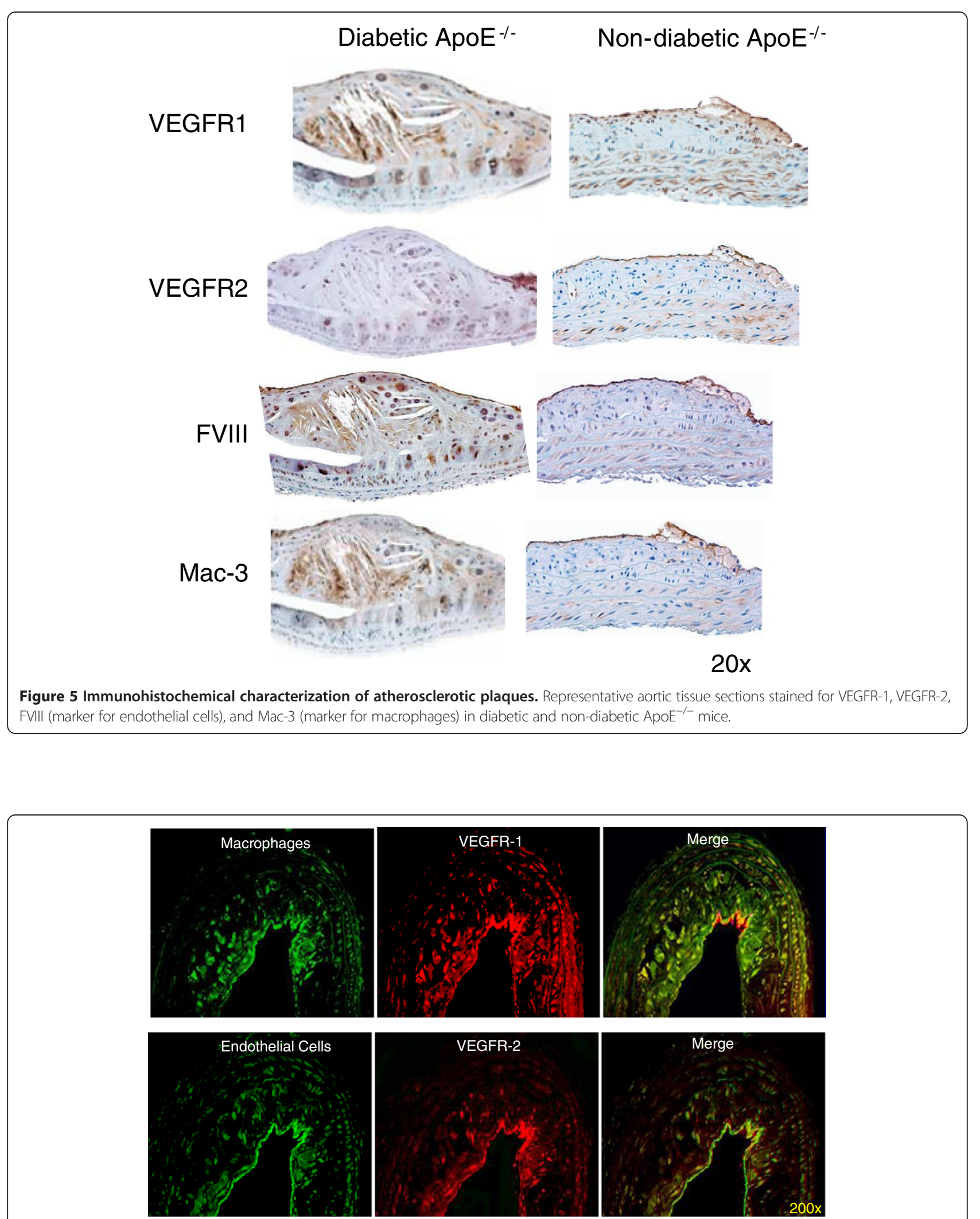

Figure 6 Differential expression of VEGFR-1 and VEGFR-2 on endothelial cells and macrophages. Double immunofluorescent staining for VEGFRs and markers of endothelial cells (FVIII) and macrophages (Mac-3). Serial atherosclerotic sections from diabetic mice were double-stained for VEGFR-1 and Mac-3 (upper row) or VEGFR-2 and FVIII (lower row), as indicated. Co-localization is visible on merged images as the yellow color. 
predominantly expressed on easily accessible luminal endothelial cells, while VEGFR-1 receptors are predominantly expressed on intraplaque macrophages. In human atherosclerosis, endothelial cells are also found in neoangiogenesis in the adventitia (vasa vasorum) and media in coronary and carotid atherosclerotic plaques associated with plaque vulnerability. These leaky capillaries express VEGR-2 on endothelial cells. The combined binding of scV/Tc to both macrophages and endothelial cells in plaque neoangiogenesis in theory provide two targets for $\mathrm{scV} / \mathrm{Tc}$ binding to boost plaque signal $[8,10,30]$. Image analysis of VEGFR-1 and VEGFR-2 independently in atherosclerotic plaques using tracers based on the known VEGF mutants [31] with predominant affinity to one receptor might further hone our ability to specifically target neoangiogenesis.

Judging by the findings in mouse aortic aneurism model [24], mouse graft arteriosclerosis model [25], and mouse urine bladder inflammation model [26], a relatively small (approximately $29 \mathrm{kDa}$ ) fluorescent scVEGF tracer can be taken up not only by readily accessible luminal endothelial cells but also by other VEGFR-expressing cells. We expect that a similarly small $(32 \mathrm{kDa}) \mathrm{scV} / \mathrm{Tc}$ tracer is also able to cross the vascular barrier and distribute between various VEGFR-expressing cells. In this respect, imaging with $\mathrm{scV} / \mathrm{Tc}$ potentially provides more target cells than ultrasound agents [23,28] or MRI agents (unpublished data) that, due to their relatively large size, are confined to the intravascular space targeting only VEGFRs on luminal endothelial cells. Of note, quantitation of $\mathrm{scV} / \mathrm{Tc}$ uptake, either from scans or from gamma counting of tissue samples, provides only the 'average' uptake values, and do not reflect significant heterogeneity in VEGFR expression, as detected by immunohistochemical analysis of our samples (Figures 5 and 6). Similar heterogeneity was observed in harvested human plaques with a fluorescent scVEGF-based tracer [28].

The uptake of ${ }^{18}$ F-FDG in arterial vessel walls signaling the high metabolic activity of inflammatory cells in atherosclerotic plaque or vasculitis has been observed and referenced extensively in the literature in both animal models and in patients [32]. The binding of $\mathrm{scV} / \mathrm{Tc}$ to VEGFR-1 expressed on macrophages indicates the similar inflammation binding target as ${ }^{18}$ FDG. Differences include the additional target of neoangiogenesis for $\mathrm{scV} / \mathrm{Tc}$ and the low constitutive expression of VEGFRs in normal myocardium. Whether these differences will translate into better specificity and signal to noise for scV/Tc vs. ${ }^{18} \mathrm{FDG}$ is yet to be determined.

The significance of our findings and, in general, the interest in imaging VEGFRs in atherosclerotic plaques are due to growing appreciation of the role of VEGF/ VEGFR signaling and enhanced VEGFR expression in atherosclerosis [10] and in vulnerable plaque [8]. Our VEGFR imaging and immunohistochemical results comparing diabetic and non-diabetic $\mathrm{ApoE}^{-/-}$mice support the emerging role of VEGFR as a biomarker for assessing complex and inflamed atherosclerotic plaques.

\section{Conclusion}

We report the first in vivo imaging study of VEGFR prevalence in atherosclerotic plaques in diabetic vs. non-diabetic atherosclerosis-prone $\mathrm{ApoE}^{-/-}$mice, a model where atherosclerosis is accelerated by diabetes. Using scVEGF-PEG-DOTA $/{ }^{99 \mathrm{~m}} \mathrm{Tc}$ SPECT tracer $(\mathrm{scV} / \mathrm{Tc})$ that binds to and is internalized by VEGFR-1 and VEGFR-2, we found enhanced uptake of the tracer in atherosclerotic plaques of diabetic vs. non-diabetic mice. The imaging findings indicate higher prevalence of VEGFRs in accelerated atherosclerosis and this conclusion is supported by immunohistochemical analyses of VEGFRs in corresponding plaques. Because higher prevalence of VEGFRs is associated with inflammation, angiogenesis, and enhanced plaque vulnerability, our findings suggest that VEGFR imaging with $\mathrm{scV} / \mathrm{Tc}$ may provide a clinically relevant biomarker of plaque vulnerability.

\section{Competing interests}

Yared Tekabe, Maria Kollaros, Adam Zerihoun, Geping Zhang, and Lynne Johnson have no competing interests. Joseph Backer and Marina Backer are employees of SibTech, Inc. that developed, patented, and supplied the sCVEGF-PEG-DOTA.

\section{Authors' contributions}

YT wrote the grant that provided funding for the experiments and supervised the conduct of the experiments and performed the radiolabeling, tracer injection, and supervised MK and AZ in performing the scans, sacrificing the mice, and obtaining tissue for histology. MK operated the scanner and assisted in handling the mice during the scans. AZ assisted YT and quantified the histological staining. GZ performed the tissue staining. $\mathrm{MB}$ and JB produced and supplied the SCVEGF-PEG-DOTA. LJ supervised the entire project, assisted in the data analysis, and manuscript preparation. All authors read and approved the final manuscript.

\section{Acknowledgements}

This work was supported by an institutional Irving Foundation imaging grant to Yared Tekabe. These internal grants for preliminary data are funded by the National Center for Advancing Translational Sciences, National Institutes of Health, through Grant Number UL1 TR000040, formerly the National Center for Research Resources, Grant Number UL1 RR024156.

\section{Author details}

'Department of Medicine, Columbia University Medical Center, 622 West 168th St, PH 10 center rm 203, New York, NY 10032, USA. 'SibTech Inc, Brookfield, CT 06804, USA.

Received: 4 April 2014 Accepted: 8 July 2014 Published: 1 August 2014

\section{References}

1. Kusters DH, Tegtmeier J, Schurgers LJ, Reutelingsperger CP: Molecular imaging to identify the vulnerable plaque-from basic research to clinical practice. Mol Imag Biol 2012, 14:523-533.

2. Quillard T, Libby P: Molecular imaging of atherosclerosis for improving diagnostic and therapeutic development. Circ Res 2012, 111:231-244.

3. Laitinen I, Saraste A, Weidl E, Poethko T, Weber AW, Nekolla SG, Leppänen P, Ylä-Herttuala S, Hölzlwimmer G, Walch A, Esposito I, Wester HJ, Knuuti J, Schwaiger M: Evaluation of alphaVbeta3 integrin-targeted positron 
emission tomography tracer ${ }^{18} \mathrm{~F}$-galacto-RGD for imaging of vascular inflammation in atherosclerotic mice. Circ Cardiovasc Imag 2009, 2:331-338.

4. Dimastromatteo J, Broisat A, Perret P, Ahmadi M, Boturyn D, Dumy P, Fagret D, Riou LM, Ghezzi C: In vivo molecular imaging of atherosclerotic lesions in ApoE-/-mice using VCAM-1-specific, ${ }^{99 \mathrm{~m}} \mathrm{Tc}$-labeled peptidic sequences. J Nucl Med 2013, 54:1442-1449.

5. Nahrendorf M, Keliher E, Panizzi P, Zhang H, Hembrador S, Fiqueiredo JL, Aikawa E, Kelly K, Libby P, Weissleder R: ${ }^{18} \mathrm{~F}-4 \mathrm{~V}$ for PET-CT imaging of VCAM-1 expression in atherosclerosis. J Am Coll Cardiol Cardiovasc Imag 2009, 2:1213-1222.

6. Nakamura I, Hasegawa K, Wada Y, Hirase T, Node K, Watanabe Y: Detection of early stage atherosclerotic plaques using PET and CT fusion imaging targeting P-selectin in low density lipoprotein receptor-deficient mice. Biochem Biophys Res Communs 2013, 433:47-51.

7. Isobe S, Tsimikas S, Zhou J, Fujimoto S, Sarai M, Branks MJ, Fujimoto A, Hofstra L, Reutelingsperger CP, Murohara T, Virmani R, Kolodgie FD, Narula N, Petrov A, Narula J: Noninvasive imaging of atherosclerotic lesions in apolipoprotein E-deficient and low-density-lipoprotein receptor-deficient mice with annexin A5. J Nucl Med 2006, 47:1497-1505.

8. Virmani R, Kolodgie FD, Burke AP, Finn AV, Gold HK, Tulenko TN, Wrenn SP, Narula J: Atherosclerotic plaque progression and vulnerability to rupture: angiogenesis as a source of intraplaque hemorrhage. Arterioscler Thromb Vasc Biol 2005, 25:2054-2061

9. Chen YX, Nakashima Y, Tanaka K, Shiraishi S, Nakagawa K, Sueishi K: Immunohistochemical expression of vascular endothelial growth factor/ vascular permeability factor in atherosclerotic intimas of human coronary arteries. Arterioscler Thromb Vasc Biol 1999, 19:131-139.

10. Holm PW, Slart RH, Zeebregts CJ, Hillebrands JL, Tio RA: Atherosclerotic plaque development and instability: a dual role for VEGF. Ann Med 2009, 41:257-264

11. Celletti FL, Hilfiker PR, Ghafouri P, Dake MD: Effect of human recombinant vascular endothelial growth factor165 on progression of atherosclerotic plaque. J Am Coll Cardiol 2001, 37:2126-2130.

12. Celletti FL, Waugh JM, Amabile PG, Brendolan A, Hilfiker PR, Dake MD: Vascular endothelial growth factor enhances atherosclerotic plaque progression. Nat Med 2001, 7:425-429.

13. Parathath S, Mick SL, Feig JE, Joaquin V, Grauer L, Habiel DM, Gassmann M, Gardner LB, Fisher EA: Hypoxia is present in murine atherosclerotic plaques and has multiple effects on macrophage lipid metabolism. Circ Res 2011, 109:1141-1152

14. Ho-Tin-Noé B, Le Dall J, Gomez D, Louedec L, Vranckx R, El-Bouchtaoui M, Legrès L, Meilhac O, Michel JB: Early atheroma-derived agonists of peroxisome proliferator-activated receptor-gamma trigger intramedial angiogenesis in a smooth muscle cell-dependent manner. Circ Res 2011, 109:1003-1014.

15. Johansson F, Kramer F, Barnhart S, Kanter JE, Vaisar T, Merrill RD, Merrill RD, Geng L, Oka K, Chan L, Chait A, Heinecke JW, Bornfeldt KE: Type 1 diabetes promotes disruption of advanced atherosclerotic lesions in LDL receptor-deficient mice. Proc Natl Acad Sci U S A 2008, 105:2082-2087.

16. Roy H, Bhardwaj S, Babu M, Kokina I, Uotila S, Ahtialansaari T, Laitinen T, Hakumaki J, Laakso M, Herzig KH, Ylä-Herttuala S: VEGF-A, VEGF-D, VEGF receptor-1, VEGF receptor-2, NF-kappaB, and RAGE in atherosclerotic lesions of diabetic Watanabe heritable hyperlipidemic rabbits. FASEB $J$ 2006, 20:2159-2161.

17. Olson FJ, Strömbert S, Hjelmgren O, Kjelldahl J, Fagerberg B, Bergström GM: Increased vascularization of shoulder regions of carotid atherosclerotic plaques from patients with diabetes. J Vasc Surg 2011, 54:1324-1331.

18. Backer MV, Levashova Z, Patel V, Jehning BT, Claffey K, Blankenberg FG, Backer JM: Molecular imaging of VEGF receptors in angiogenic vasculature with single-chain VEGF-based probes. Nat Med 2007, 13:504-509.

19. Levashova Z, Backer M, Backer JM, Blankenberg FG: Direct site-specific labeling of the cys-tag moiety in scVEGF with technetium-99 m. Bioconjug Chem 2008, 19:1049-1054.

20. Eder M, Krivoshein AV, Backer MV, Backer JM, Haberkorn U, Eisenhut M: PET - imaging of VEGF receptors with $\left[{ }^{68} \mathrm{Ga}\right]$ HBED-CC-PEG-sCVEGF. Nucl Med Biol 2010, 37:405-412

21. Blom E, Velikyan I, Monazzam A, Razifar P, Nair M, Payam Razifar P, Manoj N, Payam R, Jean-Luc V, Krivoshein AV, Marina B, Joseph B, Bengt L: Synthesis and characterization of sCVEGF-PEG- $\left[{ }^{68} \mathrm{Ga}\right]$ NOTA and sCVEGF-PEG- $\left[{ }^{68} \mathrm{Ga}\right]$ DOTA PET tracers. J Labl Compd Radiopharm 2011, 54:685-692.

22. Blankenberg FG, Levashova Z, Goris MG, Hamby CV, Backer MV, Backer JM: Targeted systemic radiotherapy with SCVEGF/ $/{ }^{177}$ Lu leads to sustained disruption of the tumor vasculature and intratumoral apoptosis. J NuCl Med 2011, 52:1630-1637.

23. Anderson CR, Rychak JJ, Backer MV, Backer J, Ley K, Klibanov AL: scVEGF microbubble ultrasound contrast agents: a novel probe for ultrasound molecular imaging of tumor angiogenesis. Invest Radiol 2010, 45:579-585.

24. Tedesco MM, Terashima M, Blankenberg FG, Levashova Z, Spin JM, Backer MV, Backer JM, Sho M, Sho E, McConnell MV, Dalman RL: Expression during experimental aortic aneurysm progression analysis of in situ and ex vivo vascular endothelial growth factor receptor. Arterioscler Thromb Vasc Biol 2009, 29:1452-47.

25. Zhang J, Razavian M, Tavakoli S, Nie L, Tellides G, Backer JM, Backer MV, Bender JR, Sadeghi MM: Molecular imaging of vascular endothelial growth factor receptors in graft arteriosclerosis. Atheroscler Thromb Vasc Biol 2012, 32:1849-1855.

26. Saban MR, Backer JM, Backer MV, Maier J, Fowler B, Davis CA, Simpson C Wu XR, Birder L, Freeman MR, Soker S, Hurst RE, Saban R: VEGF receptors and neuropilins are expressed in the urothelial and neuronal cells in normal mouse urinary bladder and are up-regulated in inflammation. Am J Physiol Renal 2008, 295:F60-F72.

27. Levashova Z, Backer MV, Backer JM, Imaging BFG, VEGF: Receptors in turpentine induced sterile thigh abscesses using radiolabeled SCVEGF $J$ Nucl. Med 2009, 50:2058-2063.

28. Lam MK, Al-Ansari S, Gooitzen M, Tio RA, Breek J, Slart RH, Hillebrands JL, Zeebregts CJ: Single-chain VEGF/Cy5.5 targeting VEGF receptors to indicate atherosclerotic plaque instability. Mol Imag Biol 2013, 15:250-261.

29. Tekabe Y, Li Q, Rosario R, Sedlar M, Majewski S, Hudson Bl, Einstein AJ, Schmidt AM, Johnson LL: Development of receptor for advanced glycation end-products directed imaging of atherosclerotic plaque in a murine model of spontaneous atherosclerosis. Circulation CV Imaging 2008, 1:212-219

30. Carr S, Farb A, Pearce WH, Virmani R, Yao JST: Atherosclerotic plaque rupture in symptomatic carotid artery stenosis. J Vas Surg 1996, 23:755-766.

31. Gille H, Kowalski J, Li B, LeCouter J, Moffat B, Zioncheck TF, Pelletier N, Ferrara N: Analysis of biological effects and signaling properties of Flt-1 (VEGFR-1) and KDR (VEGFR-2): a reassessment using novel receptorspecific vascular endothelial growth factor mutants. J Biol Chem 2001, 276:3222-3230

32. Cocker MS, MC Ardle B, Spence JD, Lum C, Hammond RR, Ongaro DC, McDonald MA, DeKemp RA, Tardif JC, Beanlands RSB: Imaging atherosclerosis with hybrid $\left[{ }^{18} \mathrm{~F}\right]$ fluorodeoxyglucose positron emission tomography/computed tomography imaging: what Leonardo da Vinci could not see. J Nucl Cardiol 2012, 19:1211-1225.

doi:10.1186/s13550-014-0041-7

Cite this article as: Tekabe et al:: Imaging VEGF receptor expression to identify accelerated atherosclerosis. EJNMMI Research 2014 4:41.

\section{Submit your manuscript to a SpringerOpen ${ }^{\odot}$ journal and benefit from:}

- Convenient online submission

- Rigorous peer review

- Immediate publication on acceptance

- Open access: articles freely available online

- High visibility within the field

- Retaining the copyright to your article

Submit your next manuscript at $>$ springeropen.com 